\title{
Rebuilding the Kariba Dam
}

\author{
Xiaoyu Zhu \\ North China Electric Power University(BAODING), Baoding 071000, China; \\ 1193341313@qq.com.
}

\begin{abstract}
The costs of rebuilding the Kariba Dam consist of demolition costs and construction costs. To evaluate the costs of reconstruction, we set up a model. In this model, partial least-squares regression analysis is carried out on the known construction costs of different dams through different periods. Then choose the dominant cost option from the model to establish the regression equation. Eventually, use the model to calculate the construction cost, and then according to the calculated construction cost, estimate the demolition cost.
\end{abstract}

Keywords: Rebuild, Construction model, Demolition cost.

\section{Introduction}

The problem requires us to do several jobs to manage the Zambezi River and offers us three options about how to manage it: Option 1) Repairing the Kariba Dam; Option 2) Rebuilding the Kariba Dam; Option 3) Removing the Kariba Dam and replacing it with a series of smaller dams along the Zambezi River. To analyze the three options listed thoroughly, decompose Option 3 is needed to us.

\section{Evaluation of the reconstruction costs}

We have searched the wiki for information on many recent dams built in Africa in the 21st century, not just in the Zambezi River Basin. Africa is chosen because the economic level and labor costs of the continents vary widely, and the selection of dams on other continents can lead to large deviations in the results.

As far as possible, we have selected 11 more reasonable dams, including the width, height, construction duration, installed capacity and construction funds of these dams.

Using these data, we calculate the correlation coefficient between each two quantities by partial least-squares and list the matrix of the cost estimation correlation coefficients, as shown in Table 1. 
Table 1. matrix of the correlation coefficient.

\begin{tabular}{|c|c|c|c|c|c|}
\hline & $\begin{array}{l}\text { Length } \\
\text { (m) }\end{array}$ & $\begin{array}{l}\text { Height( } \\
\text { m) }\end{array}$ & $\begin{array}{c}\text { installed } \\
\text { capacity(MW) }\end{array}$ & $\begin{array}{l}\text { Construction } \\
\text { duration(year) }\end{array}$ & $\begin{array}{l}\text { Money(billions } \\
\text { of dollars) }\end{array}$ \\
\hline Length(m) & 1 & 0.3634 & 0.648 & 0.1631 & 0.7325 \\
\hline Height(m) & 0.3634 & 1 & 0.5356 & 0.1267 & 0.406 \\
\hline $\begin{array}{c}\text { installed } \\
\text { capacity(MW) }\end{array}$ & 0.648 & 0.5356 & 1 & -0.1539 & 0.8521 \\
\hline $\begin{array}{l}\text { Construction } \\
\text { duration(year) }\end{array}$ & 0.1631 & 0.1267 & -0.1539 & 1 & 0.1577 \\
\hline $\begin{array}{l}\text { Money(billions of } \\
\text { dollars) }\end{array}$ & 0.7325 & 0.406 & 0.8521 & 0.1577 & 1 \\
\hline
\end{tabular}

Finally, we obtain a rough formula for calculating the cost of building a dam.The formula is as follows:

$$
Y=-7.0419+0.0143 X_{1}+0.0560 X_{2}+0.0048 X_{3}+0.2467 X_{4}
$$

Combining the basic information of the Kariba dam, the funds needed to rebuild the Kariba Dam can be derived from formula (2.1).

Table 2. Parameters of Kariba Dam

\begin{tabular}{cccccc}
\hline Dam & Length & Height & Installed capacity & Construction time & Cost(billions of dollars) \\
\hline Kariba Dam & 1750 & 128 & 1800 & 5 & 3.50246 \\
\hline
\end{tabular}

\section{Evaluation of the demolition costs}

In the case of run-time costs and benefits, solve them following the method in Option 1. The objective metrics and subjective valuations have been estimated for the rebuilt Kariba Dam.

The run-time benefits and costs of the rebuilt Kariba Dam are described in the IDAM circles shown in Figure 1. 

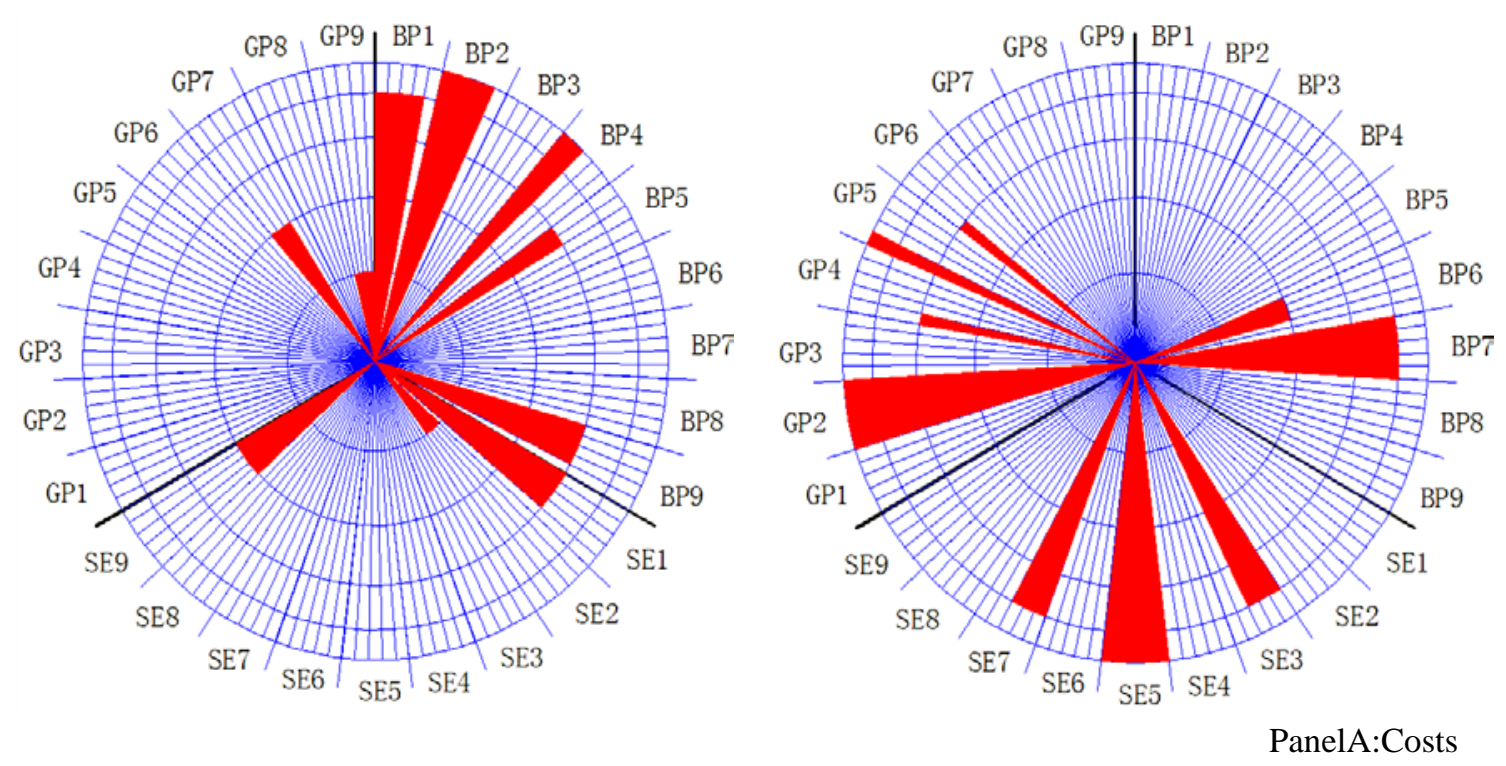

Panel B: Benefits

Figure 1. Run-time benefits and costs of the rebuilt Kariba Dam

Subtracting the total benefit (Panel B) from the total cost (Panel A) in the IDAM tool indicates a net cost of 10 units as follows: net cost of 48 units to biophysical impacts; net benefit of 23 units to socioeconomic indicators; and net benefit of 25 units to geopolitical indicators. The duration of cost recovery is $35.0246 /(0.15 \times 10)=23.35$ years.

\section{Conclusions}

From the above results,we can get the cost and benefit of rebuilding the Kariba Dam.From these data we can analyze and derive the advantages and disadvantages of this program, and thus have a more comprehensive understanding of this program.On top of these, we can compare more accurately with other different schemes to get the best solution.Of course, the analysis of this program and the calculation of data is still flawed, if there are more excellent processing model, will naturally get more accurate data, which can provide a more valuable reference for the actual situation.

\section{References}

[1] REN Xi ,KANG Tian-ke . An Application of Multi-Criteria Analysis Method in Hydropower Project. Journal of Guizhou University 2013, 30(5):31-38

[2] XING Jia ,SUN Wei-guang .Research Based on Analytic Hierarchy Process of Construction Scheme Evaluation Model of River Basin Planning Urban Sewage Treatment Plant. Environmental Science and Technology. 2015, (4)

[3] Liu Hui-fang. Stability Analysis of Watershed Silt Dams Based on Chaos Optimization and Back-Propagation. 2011, 31(3):131-135

[4] Qin Xiang-yang. Relative Stability of Dam System and Its Layout Planning Optimization Model in Small Watershed. 2010, 30(6):223-228. 